Article

\title{
Carceral Hermeneutics: Discovering the Bible in Prison and Prison in the Bible
}

\author{
Sarah Jobe \\ The Divinity School, Duke University, Durham, NC 27708, USA; sarah.jobe@duke.edu \\ Received: 16 December 2018; Accepted: 5 February 2019; Published: 10 February 2019
}

\begin{abstract}
This essay introduces the concept of "carceral hermeneutics," the art of interpreting Scripture from within prisons as, or alongside, incarcerated persons. Reading the Bible in prison reframes the Bible as a whole, highlighting how the original sites of textual production were frequently sites of exile, prison, confinement, and control. Drawing on the work of Lauren F. Winner, the author explores the "characteristic damages" of reading the Bible without attention to the carceral and suggests that physically re-locating the task of biblical interpretation can unmask interpretative damage and reveal alternative, life-giving readings. The essay concludes with an extended example, showing how the idea of cruciformity is a characteristically damaged reading that extracts Jesus' execution from its carceral context. Carceral hermeneutics surfaces a Gospel counter-narrative in which Jesus flees violence and opts for his own safety. Jesus as a refugee (Matt 2), a fugitive (Matt 4:12-17), and a victim escaping violence (Luke 4:14-30) stand alongside Jesus as an executed person to offer a wider range of options for a "christoformity" in which people can image God while fleeing from violence in order to preserve their own lives and freedom.
\end{abstract}

Keywords: incarceration; prison; carceral; hermeneutics; Bible; Matthew; Luke; exile; trauma; imago Dei; biblical exegesis; domestic violence

\section{Introduction: Locating the Carceral in the Biblical}

Where were biblical texts written, and where are biblical narratives set? When one attends to location in biblical exegesis, one finds that carceral settings pervade and permeate the Christian Scriptures. From Genesis to Revelation, the Bible includes prison literature. Jesus of Nazareth, the foundational character of the Christian faith, is a man arrested, put on trial, and executed on charges of sedition (Taylor 2015). In modern categories of genre, the four gospels could be called "true crimes." The origin stories of the church in the Book of Acts name at least nine instances of arrest and imprisonment, three of them ending in executions $(4: 3-23,5: 18-40,6: 8-15,8: 1-3,12: 1-19,16: 16-40$, 17:5-9, 19:38-41,21:33). The Apostle Paul was arrested at least four times and spends the end of his life in prison. The books of Ephesians, Philippians, Colossians, and Philemon were, self-reportedly, written from prisons (Wansink 1996; Cassidy 2001; Campbell 2018). The New Testament closes with a book of visions written by a saint who has come to be labeled by the prison at which he served his time-St. John of Patmos, exiled to a work camp under a life sentence that amounted to a death sentence, wrote the Book of Revelation from that site.

The Hebrew Bible includes stories of imprisonment at key moments. The Joseph cycle, the longest continuous narrative in Genesis, tells the story of a leader who experiences both enslavement and imprisonment in his rise to power in Egypt (Gen 37-50). Samson, the leader of Israel given the most chapters in the book of Judges, is imprisoned and escapes miraculously with God's help (Judg 15). While prison is a theme in all of the major prophets, the character of Jeremiah spends more than half of his prophetic ministry in prison, experiencing everything from house arrest to a form of solitary confinement that he believes will kill him (Jer 37-40). Additionally, prisons are not the only carceral 
contexts included in Scripture. In this article, I will use "carceral" as an adjective meaning "of or relating to prisons," but I will also use the term more broadly to indicate a wider range of experiences marked by state-sponsored control of, and violence against, both individual bodies and the social body.

Under this broader understanding of carceral, the enslavement and exile of the people of Israel are understood to be carceral. Enslavement and exile are experiences of bodily control and forced relocation away from one's home. Like all carceral contexts, enslavement and exile function through state-sponsored control of, and violence against, individual bodies and the social body. In enslavement and exile, Israel's history became marked by racialized violence, food insecurity, and sexual violence, as was and is still the case for many incarcerated people(s). While there is a growing body of literature that interprets the exile through the lenses of trauma and forced migration (Smith-Christopher 2002; Ahn 2010; Kelle et al. 2011), there is little recognition of how widely carceral terms, carceral spaces, and carceral practices constitute the grammar and geography of exilic books. At least nine books of the Bible could be considered to be "about" the Babylonian exile, and the Torah is widely understood to have been redacted in that context.

Given the carceral resonances of exile, it is no wonder that one finds the favored protagonists of these texts in various states of flight. The refugee, the nomad, the fugitive, the rebel leader, the slave, the concubine, and the political prisoner are all characters whose movements are glossed with varying degrees of criminality. Hagar, the first woman to name God, does so as she escapes violence in her home (Gen 16 and 21). Exodus paints Moses as refugee become royal (Exod 2:1-10), as a fugitive murderer fleeing capital charges (Exod 2:11-15), and as a rebel leader in various states of flight and wandering even as he leads (Exod 3-19). David, Israel's archetypal king, begins his rule in flight from Saul's administration (1 Sam 18-31). Both the Psalmist and Isaiah implicate the character of God as both a jailer who imprisons people and as the one who frees people from prison (Psa 66:11, 142:7; Isa 24:22, 42:7). The post-exilic novellas of Esther and Daniel portray their major characters navigating everything from daily food and clothing controls to genocide, the micro- and macro-aggressions of living as a captive people.

The carceral and the biblical are inextricably bound to one another. Even by conservative calculations, twenty-four of sixty-six biblical books are written from prison, from exile, or about prison and exile. ${ }^{1}$ But even given the widespread nature of the carceral in the biblical, I do not believe that I would have ever noticed these dynamics if I had not read the Bible from inside of America's prisons.

"What we see depends on where we stand," writes Elizabeth Schussler-Fiorenza in Rhetoric and Ethic: The Politics of Biblical Studies (Schussler-Fiorenza 1999, p. 19). Location matters to biblical interpretation. Schussler-Fiorenza has created a powerful legacy of pushing the guild to consider not only the context of any given text but also the social location of the interpreter as integral to the meanings one makes of Scripture. I seek to push her work a step further here, arguing that in addition to the importance of social location, the physical location in which one reads a text impacts interpretation. While this is true of any location, given the carceral contexts inherent in much of the Bible, I will argue that reading the Bible in prison serves as a particularly valuable site from which to engage the task of biblical exegesis. Carceral hermeneutics, the practice of reading the Bible from within prisons as or alongside incarcerated persons, brings to consciousness a set of dislocations, forced relocations, confinements, and controls that parallel similar movements and confinements foundational to the stories of the Bible. Though foundational, the carceral contexts of the Bible are often overlooked when interpretation occurs predominantly in non-carceral settings.

Following Lauren F. Winner, this article will move on to sketch the "characteristic damages" that can arise within biblical interpretations when exegesis occurs predominantly in non-carceral settings

1 Written from prison: parts of Jeremiah, Ephesians, Philippians, Colossians, Philemon, Revelation; written significantly about prison or about an incarcerated person: the four Gospels, Acts; written from, redacted in, or written about exile: the Torah, Isaiah, Jeremiah, Ezekiel, Lamentations, 1 and 2 Kings, 1 and 2 Chronicles, Ezra, Daniel, Esther. 
(Winner 2018). I will then conclude with an extended example, detailing one characteristic damage inherent in the history of interpretation of a set of New Testament texts used to support a theology of "cruciformity." Incarcerated women have frequently been told to "take up their cross" in the context of violent households and marriages, even unto their own deaths. Reading the text with them in prison reveals the damage of this reading while simultaneously surfacing a different set of images about who Jesus is. Jesus as a refugee (Matt 2), a fugitive (Matt 4:12-17), and a victim of violence (Luke 4:14-30) stand alongside Jesus as an executed person to offer a wider range of options for a "christoformity" in which people can image God while fleeing from violence in order to preserve their own lives.

\section{Dislocated Exegesis}

I first learned the art of "dislocated exegesis" from Charles L. Campbell and Lauren F. Winner, both of whom relentlessly tote their seminary students around town inviting the students to read particular Scriptures in places where they may not have thought to read Scripture before. Campbell writes with Stanley Saunders, "the principle is simple-where we learn shapes what we learn, and where we read shapes how we read" (Saunders and Campbell 2000, p. 89). Campbell describes taking his students to the steps of a large, downtown Atlanta bank to read and discuss James 5:1-6, a passage that warns the wealthy of the judgment that awaits those who store up wealth. He describes how the location brings the words of the text into stark relief, making impossible the artful dodging that Christians use to mitigate the biblical text's scathing social critique. In an essay called "Reading the Bible in Eight Places," Winner describes reading 1 Corinthians 13, "the love chapter," outside of an ICE Detention Center, being stunned into the realization that the words carry more meaning than their Hallmark card usage suggests (Winner 2012, pp. 134-35).

Whether they are reading the Bible in malls or bars, on buses or airplanes, in hospitals, at weddings, or in homeless shelters, both Winner and Campbell describe how dislocated exegesis prompts new perspective on biblical texts through the element of surprise. Winner defines the practice as "reading scripture in unexpected places, in places that might unsettle the assumptions you were likely to bring to the text" (Winner 2012, p. 136). Campbell describes it as "reading and studying Scripture in odd, even jarring spaces" (Campbell 2006). Both highlight how moving biblical exegesis out of the traditional sites of church, academy, and the privacy of one's own home lets the interpreter see elements of the text that she may have previously missed, dimensions of the text that are rendered invisible because they have no correlation to the interpreter's own physical and social locations. Dislocated exegesis offers a practice through which to critique and re-envision received textual interpretations, and both Winner and Campbell notice the ways in which dislocated exegesis often presses the reader toward the public and social impacts of a biblical text.

At one level, carceral hermeneutics is the practice of dislocated exegesis. Whether one enters a prison through arrest, conviction, and processing or one enters through application, background check, and a pat and frisk protocol, one's first entrance into prison is jarring. The dislocation (and the way in which one's body is handled in the process) opens up new perspectives on everything from the social function of the judicial system, to self-identity and value, to economics, to race-class-gender intersectionality. As the presumed meanings one has made in freedom are shattered and new meanings are made that account for practices of human confinement, religious sense-making is implicated as well. Reading the Bible in prison, for the first or second time, does involve submitting one's biblical interpretation to a jarring dislocation with far-ranging impacts.

But carceral hermeneutics is not a one-time practice. In a country with disproportionately long prison sentences, the dislocation from home to prison quickly settles into relocation and then simply location (Williams 2017). For those permitted to enter prisons as chaplains, educators, officers, or religious volunteers, reading the Bible in prison can become a daily or weekly practice. For any of these groups, reading the Bible in prison is a costly commitment to reading in a particular place. While prisons remain jarring even over time, prisons quickly lose their surprise. Sustaining repeated exposure to a site rife with inhumane treatment depends upon the formation of mental and emotional 
calluses to the site itself. In my experience, it is precisely because prisons cease to surprise that one can keep going into them or maintain one's sanity while living within them by force. Carceral hermeneutics is not primarily a strategy of dislocation because it is a strategy that prioritizes exegesis from prison long after the surprise of prison has faded, and the rhythms and practices of confinement and control are deeply understood by the interpreter at an experiential level.

The term "dislocated exegesis" suggests that church, academy, and home are somehow the primary or native sites of biblical interpretation and that other sites are "dislocations," surprising movements away from the expected norm. Carceral hermeneutics suggests instead that prison is a normative site from which to interpret the text for at least two reasons. Prison is a normative site for interpreting the biblical text because those confined to prison are indeed interpreting the text from that site for years, decades, and even life (Peden 2005; Boomershine 2017; Hays 2018). But prison is also a normative site for biblical exegesis because the original carceral contexts of the biblical texts themselves suggest that prisons might offer particularly salient perspectives upon texts that are deeply shaped by thousands of years of various sorts of carceral engagements. Over years of teaching together in local prisons, Winner, Campbell, and I have agreed that carceral hermeneutics might better be described as "located exegesis." Carceral hermeneutics as "located exegesis" is a commitment to reading in prisons either as, or alongside, incarcerated persons, while paying attention to one's physical location, one's social context, and to the various contexts of the biblical texts themselves.

\section{From my Context to the Bible's-Learning to Read the Distinctions and Similarities in Various Carceral Disruptions}

I have mentioned briefly that I do not think I would have ever seen any of this if I had not been reading the Bible inside, outside, and nearby prisons for the last fifteen years. I engage in carceral hermeneutics from a variety of subject positions, some of which are in conflict with one another. I have read the Bible in prison as a person who has been arrested, jailed, tried, and convicted of a crime. I currently exegete the Bible and teach exegesis in prison as an educator in a university divinity school's prison education program. I also serve as a chaplain at a women's prison, and I read the Bible in prison toward the end of preaching, Bible Study, and devotion-leading there.

I currently read the Bible in prison as a staff person who is presumed to be white within a national landscape that rhetorically races incarcerated people as black and prison staff as white-sometimes because it is true of a particular place and sometimes in an attempt to acknowledge the overwhelming racial biases operative in incarceration in the United States (Alexander [2010] 2012; Pfaff 2017). But despite the national landscape and discourse, I read the Bible in a particular prison in which the majority of the staff are black and the majority of residents are white. Specifically, $65 \%$ of the residents where I read the Bible are labeled White, 30\% Black, 2\% "Indian," and 3\% "Other," a category functionally comprising Latina women. ${ }^{2}$ While I operate in this setting as a free white woman with all the contested privileges implied therein, I am also a Patawomeck woman whose great, great-grandmother called herself white at roughly the same time when the Virginia General Assembly passed the Racial Integrity Act in 1924, one of a series of moments in which the Patawomeck people virtually disappeared into the

2 The North Carolina Department of Public Safety maintains a publicly accessible database, the Automated System Query. Available online: http://webapps6.doc.state.nc.us/apps/asqExt/ASQ. Accessed on 4 December 2018. When compared to the wider population of North Carolina, one still notes racial bias in incarceration rates in the prison where I work. According to the United States Census Bureau, in 2017 the wider North Carolina population was estimated as 70\% White, 22\% Black, 2\% American Indian, and 9\% Hispanic. United States Census Bureau, "Quick Facts: North Carolina." Available online: https://www.census.gov/quickfacts/fact/table/nc/PST045217. Accessed on 14 December 2018. I raise these specifics because there are times when the focus on the disproportionate incarceration of black men and women occludes discussion of the politics of incarceration of men and women of other races. Over the years, I have heard feedback from white, Native American, and Latina women incarcerated at the prison where I work indicating that they cannot recognize themselves in the stories told about mass incarceration in the United States. This feedback encourages a more fine-grained, state by state, and even facility by facility analysis about who is being incarcerated and the paths by which they enter prison. Such an analysis would continue to acknowledge racial bias in U.S. incarceration, but would fill in some of the gaps in that analysis. As an example, see Locked In: The True Causes of Mass Incarceration and How to Achieve Real Reform (Pfaff 2017). 
landscape of poor and middle class Virginia whiteness. Until 2010, when we received tribal recognition by the Virginia General Assembly, the Patawomeck people operated with functional invisibility and no tribal recognition. ${ }^{3}$

The dislocation of my own Patawomeck heritage continues and is highlighted each time I report to work as a chaplain because of the way in which the prison system classifies race, religion, and the credentials by which chaplains are deemed fit for service. My ordination as a Baptist pastor authorizes my presence in the prison, and I am only permitted to "officiate" Christian services, the tradition in which I am ordained. As a chaplain, I "facilitate and oversee" sixteen religious traditions recognized by the state of North Carolina, careful not to slip from "oversight" to "officiation." In practice, this means that I read the Bible as a white/Patawomeck, Christian/traditionalist woman who facilitates weekly Native American Prayer Circles but cannot smudge into those prayer circles or pray the pipe because I am ordained and credentialed as "Christian" in the eyes of the state.

The ways that being in prison dislocates these pieces of my identity is specific to my own social and physical location, but the fact that prisons destabilize identity through flattening and erasure is not unique to me. As institutions of confinement and control, prisons are stabilized by a series of classifications that necessitate that pieces of identity be simplified or erased so that individuals can be afforded and denied opportunities according to their categories. Staff or "inmate," minimum or maximum custody, male or female, security threat group or general population, Muslim or Wiccan - these classifications dictate where a body may move, where in the state a body will be housed, which foods, items, and clothing are available to any given body, whether or not a body can leave the facility, and how and when the body must return. The system cannot function without these classifications, and each body must be designated using the predetermined categories set by the state without addendum, caveat, or blurring lines of demarcation. In this process of re-locating any given body in a prison, the complex truth of that person's identity is dislocated, with varying degrees of violence depending upon whether one has gone to prison by force or by choice.

While being processed into a prison entails a series of physical dislocations and disruptions of identity, the pathways by which people become incarcerated have often already been marked by a set of movements made of both force and necessity. While it is beyond the scope of this paper to consider all the major prison pipelines, let us consider the movements inherent in three of the most common pathways to prison. First, it is widely recognized that the targeted over-policing of black men and boys has swelled incarceration rates since the 1980's (Alexander [2010] 2012). Such over-policing creates a state in which young, black men are often "on the run" well before a forced relocation to jail or prison. In her ethnography On the Run: Fugitive Life in an American City, Alice Goffman describes the ways that being constantly in flight from real or perceived threats destabilizes family networks, intimate relationships, job opportunities, and even daily practices like how one drives or eats (Goffman 2014). For black men in over-policed neighborhoods, the forced relocation to prison is one in a long line of movements, some of which (i.e., running from the police) have already been glossed with criminality.

Increasingly, Latinx communities in the United States are experiencing similar sorts of surveillance and over-policing (Rios 2011; Stuesse and Coleman 2014). Lives that are often already marked by a series of migrations and relocations across national borders are then pressed into the types of daily movements described above. For people living in the United States without documentation, apprehension by local police or Immigration and Customs Enforcement means forced relocation to a detention center, but it can also mean an additional traumatic removal of a person away from their family and livelihood to a country of origin. One who has undergone such movements (or who is perceived as having undergone them) is then described with carceral terms, whether or not a crime has been committed (Cacho 2012). Increasingly, terms like "illegal alien" have displaced identity markers

3 This is information I know through stories and tribal newsletters. For more information on the tribe see http://www. patawomeckindiantribeofvirginia.org and http:/ / www.patawomeckindians.org/index.html. 
such as refugee, immigrant, and migrant in national discourse (Zetter 2007). This dynamic of glossing non-criminal activity with carceral language will be taken up in more detail below.

Finally, one might consider the identity disruptions that commonly occur for women and girls on the road to incarceration. In their book Can't Catch a Break: Gender, Jail, Drugs, and the Limits of Personal Responsibility, Susan Starr-Sered and Maureen Norton-Hawk explain the high numbers of incarcerated women who have experienced sexual and physical abuse by noting the ways in which normal responses to coping with abuse have been criminalized (Sered and Norton-Hawk 2014). Whether a woman responds to childhood sexual assault with drug use and prostitution or to intimate partner violence with fighting back against her abuser, she will be treated as a criminal for her response. Treating victims of violence as "problems" and responding to their coping mechanisms with punishment can start when girls are still schoolchildren, especially for girls of color (Morris 2016). Sometimes these experiences of violence force physical relocations as women and girls run away from home, only to return when they find no other safe place to go. Even when these violences do not result in physical displacement, the experience of sexual assault and intimate partner violence create deep disruptions in identity for impacted women (Levi and Waldman 2011; Cox 2015). For incarcerated women, the forced displacement away from children and family in prison is simply one more dislocation in a long line of both physical disruptions and the dislocations of identity inherent in being beaten or raped by a loved one.

When one reads the Bible in the context of such forced relocations and identity disruptions, one gains eyes to see that such a fractured web of dislocations permeates, perhaps even constitutes, the biblical texts as well. In his book Holy Resilience: The Bible's Traumatic Origins, David Carr tells "the story of how the Jewish and Christian Bibles both emerged as responses to suffering, particularly group suffering (Carr 2014, p. 2)." The "group suffering" to which he refers is the series of wars that culminates in the destruction of the Jerusalem temple, the exile of much of Judah into Babylon, the Hellenistic attacks during the second temple period and the Hasmonean resistance to those, the torture and public execution of Jesus of Nazareth, and the development of the early church against the landscape of Roman occupation. While these political contexts have wild variation, they share in common that those creating the Jewish and Christian Scriptures repeatedly found themselves a conquered people condemned to the fracturing of their individual and social bodies via siege warfare, forced displacement, and military occupation. These conditions made them subject to a series of movements, confinements, and violence over which they had limited control.

The Scriptures tell some stories that are explicitly about these experiences of exile and occupation, but they also tell origin stories haunted by exile and occupation, in which the protagonists struggle to navigate their identities as people of God against the impositions of powerful nations. These navigations of identity occur within various types of movements and confinements-Abraham as nomad, Joseph as trafficked slave and prisoner, Moses as refugee, fugitive, and wanderer, Jesus on the move until his arrest and execution, Paul as repeat offender moving in and out of prison. Some of these movements and confinements are properly about the commitment of a crime and its punishment, but there are some movers-like refugees and exiles—who have not explicitly committed a crime but who are nonetheless glossed as criminal. In other words, their relocations, both forced and chosen, are described in carceral terms, regardless of whether the movements are properly about the commitment of a crime. Daniel Smith-Christopher notices that the lexicon of exile is the lexicon of prison. The words used to name "exile" in the Bible are words like "to tie," "fetter or chain," "imprison," "hold back," "place in a pit," and "bondage" (Smith-Christopher 2002, p. 72). Smith-Christopher writes, "Clearly, various forms of the Hebrew terms normally rendered "imprisonment" turn up as metaphors for exile, along with the various use of terms of binding and fetters ... Contemporary assessments of the exile must not simply dismiss this imagery as purely metaphorical with no historical basis (ibid., pp. 72-73)."

When movements or bodily controls that are not strictly about crime and punishment are glossed with the language of the carceral, they can be performing at least two rhetorical functions. First, carceral 
language can be used to described movement and confinement that is not strictly criminal because the experience of such forced movements and controls is so closely akin to the experience of prisoners that carceral language lends itself to the task of description. Exile is meant to feel punitive and operates according to some of the same control mechanisms as prison settings. Secondly, describing forced movements and confinements in carceral terms (even when they are not strictly about crime and punishment) do the work of painting the people involved in these movements and confinements as "criminals." If a group can be "criminalized," i.e., described by, or glossed with, carceral terms, then that group can be treated as criminals (re-located, bound, caged, killed) in a way that makes social sense (Jobe 2011). The description of exiles and refugees in the grammar of the carceral makes rhetorical sense of brutal confinements and relocations that would otherwise shatter the bounds of sense-making.

Carceral hermeneutics functions by enacting in the body of the biblical interpreter a set of dislocations, confinements, and controls that parallel a set of dislocations, confinements, and controls experienced by many of the writers of, and characters within, the biblical texts. For the writers and redactors of Scripture, as well as for modern biblical interpreters, these re-locations occur across a spectrum of choice and force (the difference say between a fugitive and an exile, or a refugee and a prisoner). The exact nature of the movement impacts the experiences of confinement and control in important ways (i.e., a staff person's pat and frisk is not a prisoner's strip search, a refugee's flight into a safer country is not an exile's forced march, etc.) However, attention to the distinctions between these various sorts of movement and confinements should not overlook the ways in which non-criminal movements are frequently criminalized to serve the interests of power, rendering the movements more similar than they might first seem. Neither should attention to distinctions between settings overlook the ways in which a wide variety of carceral settings function by the same mechanisms of control, regardless of whether bodies arrived in the carceral setting by force or by choice (i.e., disrupting and flattening identities, micro-controls of food and dress, forced relocations, various violences, etc.). Carceral hermeneutics uses the similarities in the way that these dynamics of movement and confinement have functioned across a wide variety of times and spaces to open up insight for modern readers into the experiences of the biblical writers and their contexts.

\section{The Interpretive Risks of Overlooking Carceral Context}

Thus far, I have shown how carceral hermeneutics is a fitting tool for exegesis, but I want to go a step further and argue that reading the Bible from prison as or alongside incarcerated persons is a necessary exegetical practice. Given the widespread carceral contexts behind the biblical texts described above, overlooking the carceral in the scriptural may well produce interpretive distortions, even mis-readings, of the Bible. Smith-Christopher, who was discussed above as noting the ways in which the grammar of exile is the grammar of prison, also notices how readings of books like Lamentations, Ezekiel, and Jeremiah quickly become metaphorical when the punitive context of exile is overlooked. He writes, "the results of literary analysis can render chains and fetters, swords and suffering unto sanitized metaphors that insulate the modern reader from the trauma of the historical exile as an event in the life of the Hebrews (Smith-Christopher 2002, p. 104)." Misunderstandings arise when one's social and physical location is so different from the social and physical location of the text that one begins to overlook the particular ways in which biblical context is shaping theological meaning. This can, of course, happen to any interpreter at any moment-we all miss dynamics as readers. I am interested, however, in the ways that some mis-readings happen in patterns, repeated again and again over centuries. I will suggest that there is a set of characteristic damages that have arisen repeatedly when interpreters have extricated particular passages and characters from their carceral contexts.

In her book, The Dangers of Christian Practice, Lauren F. Winner introduces the concept of characteristic damage. She explains that in a world marked by sin, all things experience damage, even those things that are given by God in order to draw people closer to God (eucharist, prayer, baptism, etc.). Winner acknowledges that under sin many things are damaged in ways that seem arbitrary-I could trip and drop my computer into the bathtub. However, she also notices that some things are 
damaged in ways that are characteristic of the thing itself, i.e., one can expect that because of what a book is and the goods for which a book is used, the spine of a book will crack and the edges of its pages will fox (Winner 2018, p. 4). Winner writes, "not all damage, but some damage, belongs to the form of the thing damaged, and is characteristic of it (ibid., p. 5)." Characteristic damage tells us something about the damaged thing. The characteristic damages of a practice can even tell us something about its goodness and purpose.

When Winner writes, "It is characteristic of modern academia that its participants get corrupted by pride (ibid., p. 5)," or that "it's a familiar distortion of maternal love to try to turn your kid into a better version of yourself (ibid., p. 11)," her observations sound simple and true. But Winner presses deeper to suggest that the good gifts that God gives to people are also damaged by sin, sometimes in repeated, predictable, and characteristic ways. She suggests that "supersessionism is Christianity's characteristic deformation," the perversion of intimacy with Israel's God into Christian erasure of Israel's intimacy with Israel's God (ibid., p. 37). She notices that the good of sharing each other's burdens through prayer frequently devolves into a way of "glossing gossip with piety (ibid. p. 68)." In her analysis of Christian slave-owning, she notes that, "slavery colluded with Christianity to produce ... the deformation of commandeering petitionary prayer as if it were a neutral technology, usable in the service of anything (ibid., p. 79)." Winner focuses her analysis specifically on eucharist, baptism, and prayer, but she argues that in a world of sin, every good thing is susceptible to characteristic damage.

While Winner spends the entirety of the book noting ways that Christian practices exhibit characteristic deformities, she is tempted neither to heroics nor fatalism. She does not think people can fully avoid such deformities (even though they are repeated and patterned) because the deformities have to do with the goods of the practices themselves. But neither does she advocate that people abandon deformed practices-throwing out the goods because they are marked by sin. Rather, she suggests that one receive gifts from God (baptism, eucharist, prayer, silence, marriage, the Bible) knowing "with a dual certainty that it is for good as well as for ill (ibid., p. 154)." She suggests that one receive those gifts into a matrix of gratitude, confession, repentance, and lament. Attention to the characteristic damages of the goods of Christianity might call for cessation of certain harms, as well as redress and repair of harms done, but acknowledging characteristic damage also demands lament, because even after cessation, redress, and repair, more harms will inevitably surface.

In her book, Winner does not discuss the characteristic damages of reading the Bible, but one classic damage that biblical scholars have worried over for centuries is the way in which the context of the interpreter can encourage erasures and oversights concerning the context of the text (Schussler-Fiorenza 1999). One of the goods of Scripture is that it is the gift of a text that continues to connect people to the God of Israel and to Jesus Christ over a vast array of times and places. One of the characteristic damages of applying ancient text to modern life is that the gulf between text and modern context is so broad that the interpreter will inevitably botch the analogy—for instance, seeing Babylon in every enemy (but never in one's self). In his work on dislocated exegesis, Campbell notes that when the context of the Bible is too far from the interpreter's context, the interpreter often renders metaphorical what is actually real description (Campbell 2006)—i.e., the cross becomes anything remotely taxing, fetters become anything at all that binds us, "sell all you have" becomes "donate your unwanted stuff to the local thrift store." When a text whose context is marked by forced relocation and confinement is read predominantly in free locations by people who have never experienced forced relocation or confinement, the carceral language and context of the Bible is easily glossed over, made metaphorical, or otherwise mis-interpreted.

For the church, perhaps the most dangerous refusal to acknowledge carceral context comes in readings of Jesus himself. When Jesus' execution is taken out of its carceral context, the state-sanctioned death of a condemned criminal can be read as voluntary self-sacrifice. When moving from the register of description to ethic, Jesus' self-sacrifice yields the concept of cruciformity, the idea that because Jesus willingly died on the cross, his followers should submit—silently and willingly—to violence 
against themselves, too. Reading the Bible in a women's prison taught me just how often this damaged reading of Jesus' death is used to encourage women to stay in abusive relationships and households.

I wish I could say that I remember the first time an incarcerated woman sat with me in the chaplain's office and shared her story of the ways she had been assaulted in her own home. When I search my mind for such a memory, I realize that the stories are so many and so deeply layered upon one another that excavating my own experience with this dynamic is all but impossible. For eight years, I have listened each week to a handful of stories about childhood sexual assault, rape, and domestic violence. This makes sense given the statistics of who is incarcerated in women's prisons. In the United States, nearly 1 in 5 women has been raped, and 1 in 4 women have been assaulted by their intimate partners (Sered and Norton-Hawk 2014, p. 23). Those statistics quickly triple or quadruple for incarcerated women. At least 70 percent of incarcerated women report having been raped at some point in their lives, often repeatedly, and somewhere between 60 and 94 percent of incarcerated women have experienced some form of physical or sexual abuse (ibid., p. 27). These statistics are becoming more and more well-known. What is less commonly talked about are the ways in which biblical interpretation is complicit in these figures.

One evening, I sat in a circle of some fifteen incarcerated women for a domestic violence support group. We were gathered in a double wide trailer at the back of the prison. We call the trailer "The Hope Center," and it is both our classroom and chapel. We were discussing all of the factors that make it hard to leave intimate partner violence, when one woman spoke up. "I tried to leave," she said earnestly, "I went to my pastor, and I told him what was going on at home, what he was doing to me, and the pastor told me to go back home. He said this was my way to follow Jesus, to take up my cross. After that, I never gave another thought to leaving. If the pastor thought I should stay, what more was there to do?" While a few of the women in the circle shook their heads in disappointment and frustration, more were nodding with recognition. "I had that exact same experience-take up your cross!" one exclaimed. A final woman laughed, "Girl, I didn't have to go talk to my pastor to know that's what he would have said. I'd been going to that church all my life. I know the party line."

Take up your cross. Jesus is recorded as saying some version of this in all three of the Synoptic Gospels (Matt 10:38, 16:24; Mar 8:34; Luke 9:23). In their book Proverbs of Ashes: Violence, Redemptive Suffering, and the Search for What Saves Us, Rita Nakashima Brock and Rebecca Ann Parker describe this logic of self-sacrifice and the ways in which it has kept women trapped in abusive relationships (Brock and Parker 2001). They tell excruciating stories of women who explicitly understood themselves to be following in the footsteps of Jesus by submitting to violence in their own homes, including stories of women who submitted until they were ultimately murdered by their partners. When asked by a fellow pastor what she might have done differently to prevent the murder of her congregant Anola by Anola's partner, Parker responds, "the only way you could have helped Anola more is if the whole Christian tradition taught something other than self-sacrificing love. If it didn't preach that to be like Jesus we have to give up our lives in faithful obedience to the will of God (Brock and Parker 2001, p. 19)."

In my experience, when one is bold enough to name the ways in which a doctrine of cruciformity is deadly for women, someone in the room-even a room on a prison compound-will jump to defend the doctrine. The idea of self-sacrificial love is not the problem, the defender says; rather, the application of that doctrine in situations of domestic violence is what has gone awry. However, Brock and Parker insist that the problem lies in the doctrine itself-a Christian ethic in which the goal is to march towards the cross will ultimately lead to death, but if Christ's self-sacrificial example is at the heart of the faith, what, if anything, can Christians do to mitigate suffering and violence done against themselves?

Carceral hermeneutics can help us answer this question. Jesus' execution is, in many ways, at the heart of the Christian faith. But understanding Jesus' execution to be voluntary self-sacrifice is an interpretation that ignores Jesus' carceral context. One does not describe men serving time on death row as voluntarily sacrificing their lives. In order to say such a thing of Jesus, one must ignore 
that he was a convicted criminal sentenced to state execution. No one in prison would ever suggest that someone volunteer to be strapped to a chair for lethal injection. The more time I spent in prison, the less sense the ethical imperative to self-sacrifice as an emulation of Jesus' execution made to me. I started to learn a different logic - a logic that said that getting out of prison is always a good thing. In the community where I read the Bible, if someone shares during testimony time that her sentence has been reduced, we all get up and cheer. If someone is granted parole, we all get up and cheer. During a Stations of the Cross service, when someone told the story of how she started her sentence on death row, we all shook our heads with dismay, and when she got to the part in the story where her sentence got commuted from death to life, we all got up and cheered. In this tradition of prison testimony, after the cheering, the delivered person often gives a word of encouragement to the rest of us-something along the lines of, "If God can do it for me, God can do it for you."

I began to read the story of Jesus within this logic. As I sat in the back of the worship service watching women testify to God's deliverance, I began to imagine Jesus, a tried and convicted inmate, giving his testimony, too. If Jesus stood up in a state-issued teal uniform and told his story to us in the trailer at the back of the prison, we would all shake our heads at the crucifixion. Some of us would cry, remembering the violent deaths of our own loved ones. When Jesus got to the part about how his death was commuted to life in the resurrection, every last one of us would cheer. Our congregation would cheer for so long and so loud that Jesus would have to take a good long pause in telling his story to wait for us to settle down. When placed in the context of the prison where I read the Bible, it is incomprehensible that Jesus' testimony would then end with Jesus telling the room to do their best to go get themselves sentenced to lethal injection. Cruciformity-seeking the death penalty for one's self, taking on the form of a cross-makes no sense to those like Jesus who have experienced prison, whether that prison is in Jerusalem, Rome, or the United States.

However, the women in our reading community still tell the story of Jesus' death and still see their own lives within it. They still use the language of taking up the cross. They find intimacy with Jesus in knowing that he has suffered similar imprisonments and violences to the ones they have suffered. This synergy between the stories of incarcerated people and Jesus' story is not prescriptive. In other words, the similarities are not used to suggest that incarcerated women should suffer or be killed. Rather, the similarities are descriptive. Women use them to describe the ways in which they are like Jesus at precisely the hardest moments of their lives, standing on the hope that if life after prison and execution was possible for Jesus, it is possible for them, too.

\section{A Carceral Christoformity: Jesus as Criminal, Fugitive, Victim, and Refugee}

Cruciformity is a characteristic damage of extracting Jesus' execution from its carceral context. However, like all characteristic damages, cruciformity also tells one something about the goods intrinsic to thing deformed (Winner 2018). Cruciformity as a doctrine and ethic is, at least in part, based upon the good truth that humans are made in the image of God. Christians look to Jesus as a model for how to live into the imago Dei. While carceral hermeneutics unmasks the absurdity of reading Jesus' execution as a call to seeking one's own death, carceral hermeneutics can also offer an alternative reading of the Gospels that preserves the good of being gifted Jesus as an exemplar.

As I learned to take seriously that my incarcerated congregants did not want to let go of Jesus, his cross and resurrection, or the chance to walk in his footsteps, I began searching the Scriptures for moments when Jesus flees from violence rather than accepting it. I wondered if there was a wider array of moments at which women might image Jesus than were typically presented to them. The first text I began to use in pastoral care with battered women at the prison was Luke 4:14-30. This is the story in which Jesus stands up in the synagogue in his hometown of Nazareth, unrolls the book of Isaiah, and reads the words, "The Spirit of the Lord is upon me, because he has anointed me to bring good news to the poor. He has sent me to proclaim release to the captives and recovery of sight to the 
blind, to let the oppressed go free, to proclaim the year of the Lord's favor (NRSV 4:18-19)."4 In the Gospel of Luke, this is the start of Jesus' public ministry, but Jesus is not received well by the people to whom he reads, the people of his hometown. The reader is told that, "When they heard this, all in the synagogue were filled with rage. They got up, drove him out of the town, and led him to the brow of the hill on which their town was built, so that they might hurl him off the cliff. But he passed through the midst of them and went on his way (4:28-30)."

Luke 4:14-30 is a story about home becoming an unsafe place. In this story, home is a place where Jesus' words, his identity, and his charisms are not accepted or affirmed. Nazareth, the place Jesus had been brought up (4:16), becomes a site not just of conflict but of extreme violence when Jesus' loved ones try to kill him. According to the logic of cruciformity, Jesus should have submitted willingly to this violence done against him. Instead, Jesus miraculously passes through the middle of this murderous crowd and leaves town (4:30-31). Jesus is willing to leave his home and flee to a different city in order to preserve his own life. For women seeking to be the image of God through following Jesus' example, this moment in which Jesus runs from harm must be held up as a legitimate way in which to follow the example of Christ when one is facing violence against one's self.

As I began to teach this interpretation in divinity school classes at the women's prison and to preach this interpretation in worship at the prison chapel, my pastoral care encounters with incarcerated women began to change. Alongside the stories of violence survived and the stories of pastors who had encouraged women to endure violence, I began to get a different set of questions from women trying to discern whether or not they should return to abusive environments upon release. A timid but hopeful curiosity began to build within the community as women began to wonder aloud, "is it possible that God intends something better for me than my suffering?"

This moment in his hometown is not the only time that Jesus is recorded as fleeing from violence. As I began to accept Jesus' identity as a convicted criminal who is in frequent tension with various authorities, I began to recognize that his lifestyle, always on the move in an occupied country, runs parallel to the lives of men today in over-policed communities (Goffman 2014). I began to wonder if Jesus' constant movements were first and foremost missional-the movements of an itinerant preacher-as I had been taught in my Southern Baptist Sunday School classes. Perhaps Jesus' movements are more contested than that. Perhaps they were the movements of a man understood to be a threat, fugitive movements from place to place that deter potential arrests. One possible site in which Jesus is on the move to escape arrest occurs in Matthew 4:12-17.

After the birth narratives, both Matthew and Luke move from Jesus' baptism, through his temptation in the wilderness, to a kick-off of his public ministry that is marked by violence and threat. However, in Matthew, the threat does not come from Jesus' hometown. Instead, as Jesus emerges from his trial in the desert, he "heard that John had been arrested (Matt 4:12)." Jesus has been publicly associated with John in his baptism, and we are told at the end of this passage that Jesus will take up preaching the exact message that John was preaching before his arrest (4:17). Reading this passage through the lens of the carceral, one notes that in the logic of guilt by association, John's arrest puts Jesus at risk. Jesus seems to know this. The news of John's arrest sends Jesus into a series of movements. He immediately leaves both his last known location and the region of his baptism in which he was affiliated with John to travel some 40-80km north to Nazareth (de Châtel 2014). From Nazareth he immediately travels another $30 \mathrm{~km}$ to Capernaum (4:13). In Matthew's telling, Jesus becoming an itinerant preacher is indistinguishable from Jesus, the known associate of a convict, going on the run. Jesus begins preaching John's message—repent for the kingdom of heaven is near-but he does so while moving in a way that makes it difficult for authorities to track him down (4:17). In the growing compendium of ways in which one might image Christ, it becomes possible to image Christ not only

4 Unless otherwise noted, all biblical citations are from the New Revised Standard Version. The Holy Bible: New Revised Standard Version (Metzger 1989). 
in fleeing from violence at home but also in running from the possibility of arrest. Jesus is depicted as prioritizing both his own safety and his own freedom.

Of course, in Matthew's Gospel this is not Jesus' first flight for the preservation of his life. Matthew 2:13-23 tells of a series of movements that Joseph and Mary take on Jesus' behalf in order to escape Herod's planned execution of Jesus at his birth. Shortly after Jesus is born, Joseph is warned by an angel of the Lord that Jesus' life is at risk. Joseph is commanded to take Mary and Jesus to safety in Egypt, and Joseph complies (4:13). When Herod realizes that the child he intended to kill is on the run, Herod has all the boys in Bethlehem executed (4:16-18). Jesus begins his life as a refugee child escaping a genocide intended for him. Joseph flees across national borders in order to protect his wife and child. After Herod's death, Joseph re-locates his family back to the land of Israel, but even then, their family life is not marked by a return to stability. In Joseph's estimation, the leadership in Judea continues to be a risk to Jesus, so Joseph moves his family to Nazareth instead (4:22-23).

Joseph, Mary, and Jesus might be characterized as either refugees or fugitives in this story, but regardless of the label, the holy family is marked by a series of unsanctioned relocations across national borders. They choose to make these movements against the desires of the ruling authorities because Joseph receives divine wisdom that enables him to prioritize the safety of his family and child. This story of a whole family impacted by threatened violence opens up two important resources for people seeking to image Jesus in the face of violence against themselves and their children. First, we can look like Jesus even when we cannot act to save ourselves and someone must step in to move us toward safety and freedom. Women cannot escape violent households on their own. For a woman to relocate out of a violent household, there must be networks of people willing to prioritize the safety of those being threatened. Secondly, this passage is good news for the mothers and fathers of threatened children. Matthew 2:13-23 encourages us to not only see Jesus in ourselves but to move to places in which our children can grow into the image of Christ. Children are worth saving, even when that entails flights from violent authorities across national borders. When mothers and fathers make decisions to act in unsanctioned ways against governing authorities for the safety of targeted children, they are following a pattern offered by the holy family. Such carceral actions toward the safety of targeted children illuminates the image of Christ in our sons and daughters.

Reading the Gospels with an eye to the carceral surfaces the moments in which Jesus acts to preserve his own life as he operates in the categories of refugee, fugitive, and victim of violence. Holding Jesus' various movements alongside his ultimate execution offers people a way to follow Jesus' example, even as they move to save their own lives. This wider "christoformity" stretches backward from Jesus' death to encompass all of Jesus' life. It preserves the good of imaging God, while enabling people to image God in their pursuit of their own safety, freedom, and flourishing. Reading Jesus in his carceral context reverses the characteristically damaged readings of Jesus that arise when his death is removed from the context of his imprisonment. Carceral hermeneutics offers a correction to a misinterpretation of the cross as voluntary self-sacrifice, but carceral hermeneutics also brings attention to the other moments of Jesus' life that parallel the experiences of men and women incarcerated in other times and places. Reading the Bible in prison, as or alongside incarcerated persons, enables the interpreter to notice when the carceral is operative in the Bible, take that context seriously in the act of interpretation, and simultaneously allow the Bible to speak a word of illumination, condemnation, and restoration to the carceral contexts of our world today.

Funding: This research received no external funding.

Acknowledgments: I wish to thank Lauren Winner, a partner in every aspect of this work. You are indispensable to my thinking, my writing, and my life. I also wish to thank the many people who have joined me in reading the Bible in prison: Thea Portier-Young, Chuck Campbell, Ross Wagner, Susan Eastman, Douglas Campbell, and the women of North Carolina Correctional Institution for Women among them. Finally, my thanks to both Luke Bretherton and J. Kameron Carter for challenging me to think, in ever more pointed ways, about fugitivity, exile, and the goods and ills of living on the run.

Conflicts of Interest: The author declares no conflict of interest. 


\section{References}

Ahn, John J. 2010. Exile as Forced Migrations: A Sociological, Literary, and Theological Approach on the Displacement and Resettlement of the Southern Kingdom of Judah. New York: De Gruyter.

Alexander, Michelle. 2012. The New Jim Crow: Mass Incarceration in the Age of Color Blindness. New York: The New Press. First published 2010.

Boomershine, Amelia C. 2017. A Breath of Fresh Air: Biblical Storytelling with Prisoners. Eugene: Cascade.

Brock, Rita Nakashima, and Rebecca Ann Parker. 2001. Proverbs of Ashes: Violence, Redemptive Suffering, and the Search for What Saves Us. Boston: Beacon Press.

Cacho, Lisa Marie. 2012. Social Death: Racialized Rightlessness and the Criminalization of the Unprotected. New York: New York University Press.

Campbell, Charles. 2006. Dislocated Exegesis. Paper presented at the Academy of Homiletics, Columbia Theological Seminary, Decatur, GA, USA, December 1.

Campbell, Douglas A. 2018. Mass Incarceration: Pauline Problems and Pauline Solutions. Interpretations: A Journal of Bible and Theology 72: 282-92. [CrossRef]

Carr, David M. 2014. Holy Resilience: The Bible's Traumatic Origins. New Haven: Yale University Press.

Cassidy, Richard J. 2001. Paul in Chains: Roman Imprisonment and the Letters of St. Paul. New York: Crossroads Publishing Company.

Cox, Aimee Meredith. 2015. Shapeshifters: Black Girls and the Choreography of Citizenship. Durham: Duke University Press.

de Châtel, F. 2014. Baptism in the Jordan River: immersing in a contested transboundary watercourse. WIREs Water 1: 219-27. [CrossRef]

Goffman, Alice. 2014. On the Run: Fugitive Life in an American City. New York: Picador.

Hays, Joshua. 2018. Reading Scripture in Exile: Favorite Scriptures among Maximum-Security Inmates Participating in Prison Seminary Programs. In Finding Freedom in Confinement: the Role of Religion in Prison Life. Edited by Kent R. Kerley. Santa Barbara: Praeger.

Jobe, Sarah. 2011. Portrait of a Ministry: Project TURN. In Christian Reflection: A Series in Faith and Ethics. Waco: Baylor University.

Kelle, Brad, Frank R. Ames, and Jacob L. Wright, eds. 2011. Interpreting Exile: Displacement and Deportation in Biblical and Modern Contexts. Atlanta: Society of Biblical Literature.

Levi, Robin, and Ayelet Waldman, eds. 2011. Inside This Place, Not of It: Narratives from Women's Prisons. San Francisco: McSweeney's Books.

Metzger, Bruce M. 1989. The Holy Bible: New Revised Standard Version. Nashville: Thomas Nelson Publishers.

Morris, Monique W. 2016. Pushout: The Criminalization of Black Girls in Schools. New York: The New Press.

Peden, A. 2005. Contextual Bible Study at Cornton Vale Women's Prison, Stirling. The Expository Times 117: 15-18. [CrossRef]

Pfaff, John. 2017. Locked In: The True Causes of Mass Incarceration and How to Achieve Real Reform. New York: Basic Books.

Rios, Victor M. 2011. Punished: Policing the Lives of Black and Latino Boys (New Perspectives on Crime, Deviance, and the Law. New York: New York University Press.

Saunders, Stanley P., and Charles L. Campbell. 2000. The Word on the Street: Performing the Scriptures in the Urban Context. Eugene: Wipf and Stock Publishers.

Schussler-Fiorenza, Elizabeth. 1999. Rhetoric and Ethic: The Politics of Biblical Studies. Minneapolis: Fortress Press.

Sered, Susan Starr, and Maureen Norton-Hawk. 2014. Can't Catch a Break: Gender, Jail, Drugs, and the Limits of Personal Responsibility. Oakland: University of California Press.

Smith-Christopher, Daniel L. 2002. A Biblical Theology of Exile. Minneapolis: Augsberg Fortress.

Stuesse, Angela, and Mathew Coleman. 2014. Automobility, Immobility, Altermobility. City and Society 26: 51-72. [CrossRef]

Taylor, Mark Lewis. 2015. The Executed God: The Way of the Cross in Lockdown America, 2nd Edition. Minneapolis: Fortress Press.

Wansink, Craig S. 1996. Chained in Christ: The Experience and Rhetoric of Paul's Imprisonments. Sheffield: Sheffield Academic Press. 
Williams, Janice. 2017. Serving Time: Average Prison Sentence in the U.S. is Getting Even Longer. Newsweek, July 22. Available online: https:/ / www.newsweek.com/prison-sentences-increased-2017-jail-639952 (accessed on 14 December 2018).

Winner, Lauren F. 2012. Still: Notes on a Mid-Faith Crisis. New York: Harper Collins.

Winner, Lauren F. 2018. The Dangers of Christian Practice: One Wayward Gifts, Characteristic Damage, and Sin. New Haven: Yale University Press.

Zetter, Roger. 2007. More Labels, Fewer Refugees: Remaking the Refugee Label in an Era of Globalization. Journal of Refugee Studies 20: 172-92. [CrossRef]

(c) (2)

(C) 2019 by the author. Licensee MDPI, Basel, Switzerland. This article is an open access article distributed under the terms and conditions of the Creative Commons Attribution (CC BY) license (http:/ / creativecommons.org/licenses/by/4.0/). 